\title{
Testing the antagonistic effect of follistatin on BMP family members in ovine granulosa cells
}

\author{
Alice PIERre, Claudine PISSELET, Philippe Monget, \\ Danielle MONNIAUX, Stéphane FABRE*
}

INRA, Physiologie de la Reproduction et des Comportements, UMR 6175 INRA-CNRS-Université de Tours-Haras Nationaux, 37380 Nouzilly, France

(Received 29 April 2004; accepted 8 March 2005)

\begin{abstract}
Follistatin was first demonstrated as an activin-binding protein, neutralizing its actions. However, there is emerging evidence that follistatin inhibits the action of other members of the transforming growth factor $\beta$ (TGFß) / bone morphogenetic protein (BMP) superfamily. Recently, numerous BMP factors have been shown to play important roles in regulating folliculogenesis and ovulation rate in mammals, and such a potential antagonistic role of follistatin is of particular interest in the context of ovarian function. Using a biological test based on progesterone production by ovine primary granulosa cells in culture, we show that follistatin was a strong antagonist of activin A, but not BMP-2 or BMP-4 actions. In contrast, noggin, a known specific BMP antagonist, had no effect on activin A but strongly neutralized BMP-2 and BMP-4 actions. BMP-6 action was only slightly reduced by both follistatin and noggin. Our data led to the conclusion that follistatin would not represent a determinant physiological modulator of the biological effect of BMP factors on granulosa cells.
\end{abstract}

ovary / granulosa cells / follistatin / noggin / bone morphogenetic protein

\section{INTRODUCTION}

Follistatin was first described as a gonadal inhibitor of FSH secretion from pituitary cells, suggesting that it would act in an endocrine way. It is now clear that follistatin most likely acts as a paracrine/autocrine factor in a number of tissues. Follistatin has been demonstrated as an activinbinding protein, neutralizing the action of activin [1]. Two mature follistatin isoforms of 288 and 315 amino acids encoded by a single gene arising from alternative splicing exist $[2,3]$. The relative importance of the two isoforms (follistatin-288 and follistatin-315) is discussed with particular emphasis on the regulation of the ovaries. Follistatin-288 is the predominant form present in human follicular fluid [4]. In mammalian ovaries, follistatin is highly expressed by the granulosa cells (GC) of developing follicles [5-7]. The level of follistatin mRNA expression within the antral follicles increases as follicular maturation progresses and declines during the atretic process $[5,8]$. Follistatin has been shown to block all the actions of activin on GC, including the stimulation of FSH receptor expression, inhibin

* Corresponding author: sfabre@tours.inra.fr 
secretion and steroidogenesis regulation [9]. In addition, follistatin has been recently shown to bind and regulate the function of other members of the TGFB/BMP family, thereby expanding its range of action. Indeed, follistatin antagonizes the action of BMP-2, BMP-4 and BMP-7 in the xenopus embryo $[10,11]$ or BMP-7 in the development of chick limbs [12]. Follistatin can also inhibit the action of GDF-8/myostatin, another TGFß/BMP family member, controlling skeletal muscle mass [13]. Interestingly, transgenic mice overexpressing follistatin exhibited different phenotypes than those seen in mice deficient for the activin subunits or activin receptor [14]. Therefore, the in vivo effect of follistatin might be caused by the inhibition of the activins and/ or the BMP.

Altogether, these observations indicate that follistatin is not only an activin-binding protein, but would also interact with other TGFß/BMP family members, through a probable similar binding mechanism. This hypothesis is of particular interest in the context of ovarian physiology, since different BMP family members have been shown to be involved in controlling the growth of preantral follicles, GC differentiation and ovulation rate (for reviews [15-17]).

In order to address this issue, we performed an in vitro biological test using ovine primary GCs to evaluate the neutralizing effect of follistatin and noggin, a specific BMP antagonist [18], on the action of different members of the BMP/TGFß system (activin A, BMP-2, BMP-4 and BMP-6). This work was based on previous observations of similar inhibitory action of BMP-4 and activin $A$ on progesterone secretion by ovine GC [19].

\section{MATERIALS AND METHODS}

\subsection{Animals}

Cyclic Romanov ewes were treated with intravaginal progestagen sponges (fluoro- gestone acetate, $40 \mathrm{mg}$, Intervet, Angers, France) for 13 days in order to synchronize oestrus. The ovaries were recovered after castration in the late follicular phase, $36 \mathrm{~h}$ after sponge removal. All procedures were approved by the agricultural and scientific research Government committees in accordance with the guidelines for the Care and Use of Agricultural Animals in Agricultural Research and Teaching (approval A37801).

\subsection{Granulosa cell cultures}

Briefly, in each independent culture experiment, ovarian follicles from three ewes were quickly dissected, pooled and classified according to size. GC were recovered from small antral follicles (1-3 mm in diameter) as previously described [20]. GC suspensions were seeded at 100000 viable cells/well in 96-well plates and cultured for $96 \mathrm{~h}$ at $37{ }^{\circ} \mathrm{C}$ with $5 \% \mathrm{CO}_{2}$ in serumfree McCoy 5a medium (Sigma, L'Isle d'Abeau Chesnes, France) containing IGF-1 (10 ng. $\mathrm{mL}^{-1}$, Ciba-Geigy, Saint-Aubin, Switzerland), according to a previously described method [21]. Cultures were performed with or without recombinant human activin A, BMP-2, BMP-4 or BMP-6 (R\&D Systems, Lille, France), each alone or in combination with recombinant mouse follistatin-288 (R\&D Systems, Lille, France) or recombinant human noggin (Regeneron Pharmaceuticals, Tarrytown, NY, USA). Each combination of treatments was tested in triplicate in each of four independent culture experiments. Culture media were partially replaced (180 over $250 \mu \mathrm{L})$ at $48 \mathrm{~h}$. Media conditioned between 48 and $96 \mathrm{~h}$ of culture were collected at $96 \mathrm{~h}$ and stored at $-20{ }^{\circ} \mathrm{C}$ prior to the progesterone assay. At the end of the culture period, the number of cells per well was estimated after trypsinization with a hemacytometer under a phase contrast microscope. In our culture conditions, the cell number was not affected by the different combination of treatments. 


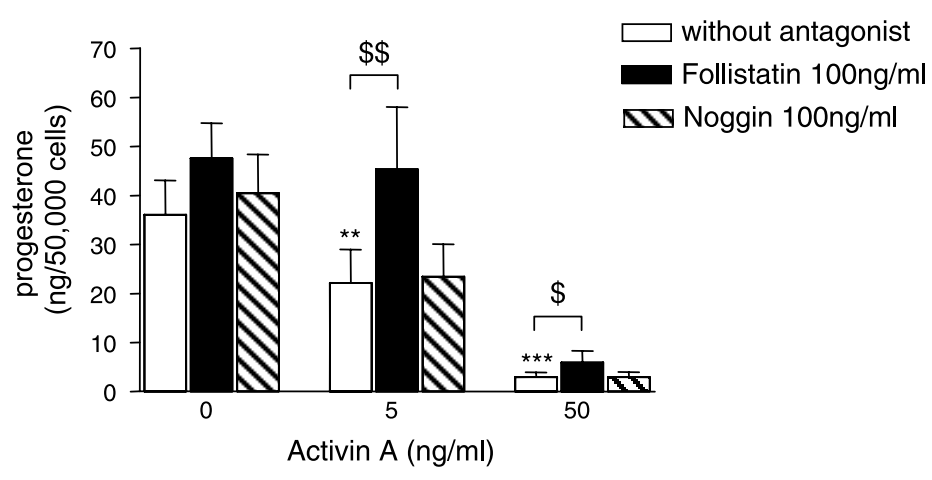

Figure 1. The effect of follistatin and noggin on activin A activity. GC from small antral (1-3 mm in diameter) ovine follicles were cultured for $96 \mathrm{~h}$ in serum-free conditions. Cultures were performed in the absence (control) or in the presence of follistatin $\left(100 \mathrm{ng} \cdot \mathrm{mL}^{-1}\right)$ or noggin $\left(100 \mathrm{ng} \cdot \mathrm{mL}^{-1}\right)$, each alone or in combination with activin A $\left(5\right.$ or $\left.50 \mathrm{ng} \cdot \mathrm{mL}^{-1}\right)$. Each combination of treatments was tested in triplicate in each of 3 independent experiments. The results represent the amount of progesterone secreted by $50000 \mathrm{GC}$ between $48 \mathrm{~h}$ and $96 \mathrm{~h}$ of culture. $* * P<0.01, * * * P<0.001$, activin A vs. an untreated condition; $\$ P<0.05, \$ \$ P<0.01$ with vs. without antagonist for each dose of activin A.

\subsection{Progesterone radioimmunoassay}

Progesterone amounts in the culture media from each experiment were measured by radioimmunoassay in the same assay, as described [22]. The limit of detection of the assay was $12 \mathrm{pg} \cdot$ tube $^{-1}$ and the intra-assay coefficient of variation was $10 \%$. The results are expressed as the amount of progesterone secreted per 50000 cells recovered at the end of the culture period.

\subsection{Data analysis}

The data are presented as mean \pm SEM. The effects of treatments on progesterone secretion were analysed by Super ANOVA software (Abacus Concepts, Inc.). The effect of activin and BMP were analyzed using two-way ANOVA in order to appreciate the ligand as well as the culture effect resulting from variations between both animals and the quality of the ovarian follicles dissected for each culture. The effects of antagonists (follistatin and noggin) were analyzed in a similar way for each dose of the ligand (activin or BMP). Post-hoc comparisons were performed with the Scheffe and NewmanKeuls tests. Differences with $P>0.05$ were considered as not significant.

\section{RESULTS}

As shown in Figure 1, the addition of increasing doses of activin A led to a dosedependent inhibition of progesterone secretion by ovine GC as previously shown [19] (Fig. 1A). Treating GC with follistatin or noggin, each alone, at $100 \mathrm{ng} \cdot \mathrm{mL}^{-1}$ had no effect on progesterone production. However, follistatin completely abolished (activin A $5 \mathrm{ng} \cdot \mathrm{mL}^{-1}, P<0.01$ ) or significantly reduced (activin A $50 \mathrm{ng} \cdot \mathrm{mL}^{-1}, P<0.05$ ) the inhibiting effect of activin $\mathrm{A}$ on progesterone secretion. In contrast, noggin was without an effect on the response of GC to activin A. Thus, as expected, follistatin, but not noggin, neutralized the effect on activin A on GC steroidogenesis.

We next investigated the effect of follistatin on the response of GC to other BMP/ TGFß family members in order to appreciate its specificity of action in the context of ovarian cells. As shown in Figure 2, BMP-2, 

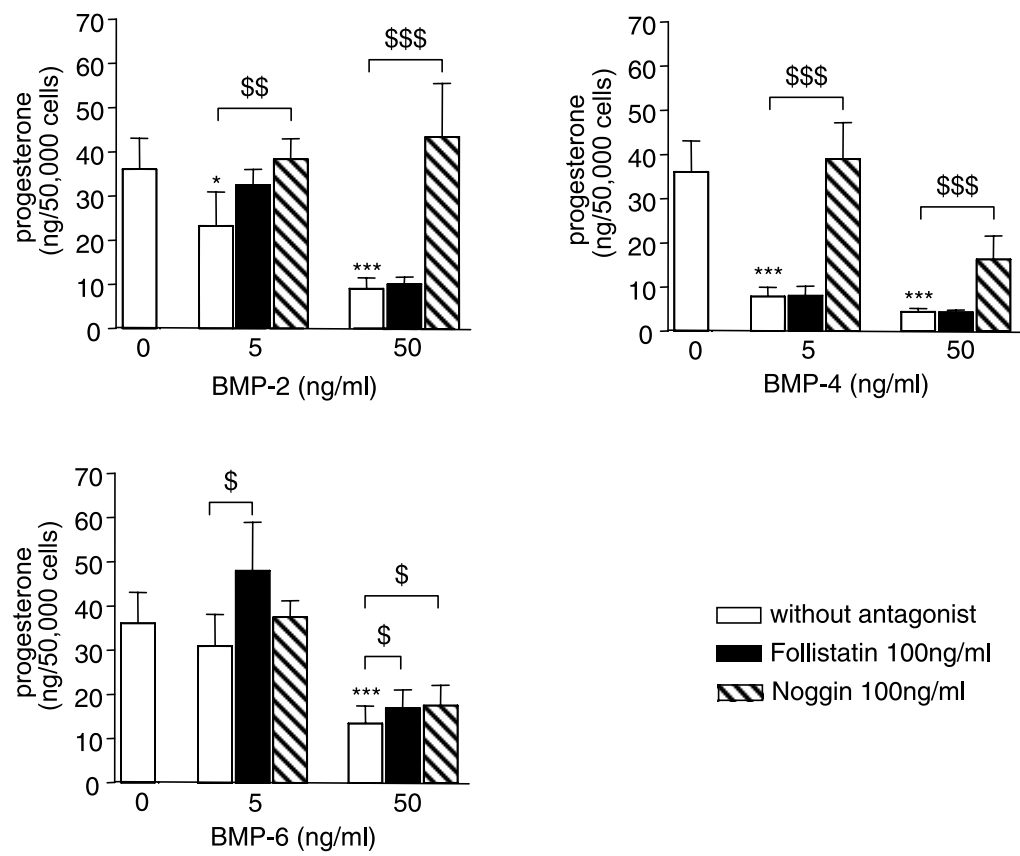

Figure 2. The effect of follistatin and noggin on BMP factors activity. Experimental conditions were the same as in Figure 1. Ovine GC were cultured in the absence or in the presence of various doses of BMP-2 or BMP-4 or BMP-6, each alone (control) or in combination with follistatin $\left(100 \mathrm{ng} \cdot \mathrm{mL}^{-1}\right)$ or noggin $\left(100 \mathrm{ng} \cdot \mathrm{mL}^{-1}\right)$. $* P<0.05, * * * P<0.001$, BMP factor vs. untreated condition; $\$ P<$ $0.05, \$ \$ P<0.01, \$ \$ \$ P<0.001$, with vs. without antagonist for each dose of the BMP factor.

BMP-4 and BMP-6 dose-dependently inhibited progesterone secretion by ovine GC. Follistatin did not significantly change the GC response to BMP-2 or BMP-4. In striking contrast, and as expected, noggin strongly abolished both BMP-2 and BMP-4 actions $(P<0.001)$. The action of BMP-6 was slightly reduced by both follistatin and nog$\operatorname{gin}(P<0.05)$.

\section{DISCUSSION}

In this study, we performed an analysis of the neutralizing effect of follistatin on the action of various TGF//BMP factors using progesterone production by ovine primary $\mathrm{GC}$ as an in vitro biological test. Our data led to the conclusion that follistatin was a strong antagonist of the actions of activin A, but not BMP factors, on GC. Particularly, follistatin did not affect BMP-2 and BMP-4 actions on GC, while noggin, a true BMP antagonist, clearly inhibited their actions. In contrast, BMP-6 action was slightly inhibited by follistatin, in accordance with recent results in bovine GC [23].

In the ovaries of most mammals, $\mathrm{GC}$ are responsible for producing and secreting follistatin (for review [9]). In sheep, follistatin expression is detectable in preantral follicles, increasing as follicular maturation progresses and declining during atresia. Primordial and primary follicles do not express follistatin mRNA [7, 24], indicating that follistatin may not be implicated in early stages of follicular development. Among TGFß/BMP family members present in the 
ovaries, oocyte-derived GDF-9, BMP-15 and BMP-6 are expressed from the primordial to the preovulatory stage of follicular development in rodents and ruminants. GDF-9 and BMP-15 are of critical importance at very early stages of folliculogenesis, controlling primary to secondary follicle transition $[15,16]$. In later stages, it has been established that removal of the oocyte from antral follicle induces luteinization of follicular cells [25], suggesting that the oocyte is the source of anti-luteinizing factors. Interestingly, recombinant GDF-9, BMP15 and BMP-6 have been shown to modulate the FSH differentiating action on GC in vitro and to delay the luteinization process [26-28]. This suggests that oocyte-derived BMP could be such anti-luteinizing factors. Among the three oocyte-derived BMP identified yet, follistatin has been shown to bind and reduce the activity of BMP-15 [29] and BMP-6 ([23], and the present study), reinforcing its role as a luteinizing factor of GC in large antral follicles. In contrast, due to its pattern of expression, follistatin is not expected to interfere with the action of these oocyte-derived BMP factors on the first stages of folliculogenesis.

Follicular cells of secondary to antral follicles have also been shown to express other various BMP factors, such as BMP-2, BMP-3, BMP-4 and BMP-7, concomitantly with follistatin [30-32]. In vitro experiments using recombinant BMP-2, BMP-4 or BMP-7 have designated these BMP, as well as oocyte-derived BMP, as anti-luteinizing factors $[19,32,33]$. From our experiments, follistatin would not be a modulator of the action of either BMP-2 or BMP-4 on GC. In contrast, recent results of Glister et al. [23] indicate that follistatin is able to bind BMP-4 and inhibits BMP-4 dependent Smad-1 phosphorylation in bovine GCs. This discrepancy might be due to the species difference of the recombinant follistatin used, which was the mouse in the present study and the human in the study of Glister et al. [23]. Alternatively, the sensitivity of our biological test might not be sufficient to show an effect of follistatin, the affinity of which being 10-fold lower for BMP-4 than for activin A [23].

In our experiments, noggin was able to strongly inhibit BMP-2 and BMP-4, but weakly BMP-6 actions on ovine GC. These results were in agreement with the known effects of noggin in other cell types. Particularly, noggin has been reported to be a strong antagonist of BMP-2 and BMP-4, but a weak antagonist of BMP-7, which is structurally related to BMP-6 $[18,34]$.

Noggin did not seem to be expressed in the ovine ovaries when the RT-PCR approach was used (S. Fabre, data not shown). Valenzuela et al. [35] also failed to detect noggin mRNA in rat ovaries, suggesting that noggin does not represent a physiological antagonist of BMP factors in the ovaries. In contrast, another BMP antagonist, chordin, functionally related to noggin (reviewed in [34]), has been shown to be expressed by human ovaries [36]. Accordingly, by RT-PCR, we detected chordin mRNA in ovine ovaries (S. Fabre, unpublished data). Thus, this raises the possibility that in the ovaries, at least two antagonists of BMP and BMP-related factors might participate in modulating their anti-luteinizing actions on GC. Follistatin could mostly inhibit activin A, oocyte-derived BMP-15 and BMP- 6 actions, and chordin might more specifically modulate BMP-2 and BMP-4 actions. Further experiments are needed to support this hypothesis.

In this study, we showed that follistatin did not antagonize BMP-2 or BMP-4 actions on ovine GC and only had a slight modulatory effect on BMP-6 actions. It is hypothesized that follistatin does not represent a determinant physiological modulator of the action of these BMP factors. The existence of more specific antagonists able to control the function of those and other BMP molecules (GDF-9 and BMP-7) and their physiological relevance in ovarian function remains to be investigated. 


\section{ACKNOWLEDGEMENTS}

We are grateful to Dr. N. Stahl from Regeneron Pharmaceuticals for providing the noggin protein. We also thank F. Dupont and the staff of the ovine experimental unit in Nouzilly for the in vivo treatments to the animals. This work was supported in part by Intervet Pharma R\&D, Angers, France. A. Pierre was supported by a French fellowship from the "Région Centre".

\section{REFERENCES}

[1] Nakamura T, Takio K, Eto Y, Shibai H, Titani $\mathrm{K}$, Sugino $\mathrm{H}$. Activin-binding protein from rat ovary is follistatin. Science 1990, 247: 836838.

[2] Shimasaki S, Koga M, Esch F, Cooksey K, Mercado M, Koba A, Ueno N, Ying SY, Ling N, Guillemin R. Primary structure of the human follistatin precursor and its genomic organization. Proc Natl Acad Sci USA 1988 , 85: 4218-4222.

[3] Shimasaki S, Koga M, Esch F, Mercado M, Cooksey K, Koba A, Ling N. Porcine follistatin gene structure supports two forms of mature follistatin produced by alternative splicing. Biochem Biophys Res Commun 1988, 152: 717-723.

[4] Schneyer AL, Hall HA, Lambert-Messerlian G, Wang QF, Sluss P, Crowley WF Jr. Follistatin-activin complexes in human serum and follicular fluid differ immunologically and biochemically. Endocrinology 1996, 137: 240-247.

[5] Roberts VJ, Barth S, El-Roeiy A, Yen SS Expression of inhibin/activin subunits and follistatin messenger ribonucleic acids and proteins in ovarian follicles and the corpus luteum during the human menstrual cycle. J Clin Endocrinol Metab 1993, 77: 1402-1410.

[6] Shimasaki S, Koga M, Buscaglia ML, Simmons DM, Bicsak TA, Ling N. Follistatin gene expression in the ovary and extragonadal tissues. Mol Endocrinol 1989, 3: 651-659.

[7] Tisdall DJ, Hudson N, Smith P, McNatty KP. Localization of ovine follistatin and alpha and beta A inhibin mRNA in the sheep ovary during the oestrous cycle. J Mol Endocrinol 1994, 12: 181-193.

[8] Lindsell CE, Misra V, Murphy BD. Regulation of follistatin gene expression in the ovary and in primary cultures of porcine granulosa cells. J Reprod Fertil 1994, 100: 591-597.
[9] Lin SY, Morrison JR, Phillips DJ, de Kretser DM. Regulation of ovarian function by the TGF-beta superfamily and follistatin. Reproduction 2003, 126: 133-148.

[10] Fainsod A, Deissler K, Yelin R, Marom K, Epstein M, Pillemer G, Steinbeisser H, Blum $M$. The dorsalizing and neural inducing gene follistatin is an antagonist of BMP-4. Mech Dev 1997, 63: 39-50.

[11] Iemura S, Yamamoto TS, Takagi C, Uchiyama H, Natsume T, Shimasaki S, Sugino H, Ueno N. Direct binding of follistatin to a complex of bone-morphogenetic protein and its receptor inhibits ventral and epidermal cell fates in early Xenopus embryo. Proc Natl Acad Sci USA 1998, 95: 9337-9342.

[12] Amthor H, Christ B, Rashid-Doubell F, Kemp $\mathrm{CF}$, Lang E, Patel K. Follistatin regulates bone morphogenetic protein-7 (BMP-7) activity to stimulate embryonic muscle growth. Dev Biol 2002, 243: 115-127.

[13] Lee SJ, McPherron AC. Regulation of myostatin activity and muscle growth. Proc Natl Acad Sci USA 2001, 98: 9306-9311.

[14] Matzuk MM, Kumar TR, Shou W, Coerver KA, Lau AL, Behringer RR, Finegold MJ. Transgenic models to study the roles of inhibins and activins in reproduction, oncogenesis, and development. Recent Prog Horm Res 1996, 51: 123-154.

[15] Elvin JA, Yan C, Matzuk MM. Oocyteexpressed TGF-beta superfamily members in female fertility. Mol Cell Endocrinol 2000, 159: 1-5.

[16] McNatty KP, Juengel JL, Wilson T, Galloway SM, Davis GH, Hudson NL, Moeller CL, Cranfield M, Reader KL, Laitinen MP, Groome NP, Sawyer HR, Ritvos O. Oocytederived growth factors and ovulation rate in sheep. Reprod 2003, 61 (Suppl): 339-351.

[17] Monget P, Fabre S, Mulsant P, Lecerf F, Elsen JM, Mazerbourg S, Pisselet C, Monniaux D. Regulation of ovarian folliculogenesis by IGF and BMP system in domestic animals. Domest Anim Endocrinol 2002, 23: 139-154.

[18] Zimmerman LB, De Jesus-Escobar JM, Harland RM. The Spemann organizer signal noggin binds and inactivates bone morphogenetic protein 4. Cell 1996, 86: 599-606.

[19] Fabre S, Pierre A, Pisselet C, Mulsant P, Lecerf F, Pohl J, Monget P, Monniaux D. The Booroola mutation in sheep is associated with an alteration of the bone morphogenetic protein receptor-IB functionality. J Endocrinol 2003, 177: 435-444. 
[20] Monniaux D, Pisselet C. Control of proliferation and differentiation of ovine granulosa cells by insulin-like growth factor-I and follicle-stimulating hormone in vitro. Biol Reprod 1992, 46: 109-119.

[21] Campbell BK, Scaramuzzi RJ, Webb R. Induction and maintenance of oestradiol and immunoreactive inhibin production with FSH by ovine granulosa cells cultured in serumfree media. J Reprod Fertil 1996, 106: 7-16.

[22] Saumande J. Culture of bovine granulosa cells in a chemically defined serum-free medium: the effect of insulin and fibronectin on the response to FSH. J Steroid Biochem Mol Biol 1991, 38: 189-196.

[23] Glister C, Kemp CF, Knight PG. Bone morphogenetic protein (BMP) ligands and receptors in bovine ovarian follicle cells: actions of BMP-4, -6 and -7 on granulosa cells and differential modulation of Smad-1 phosphorylation by follistatin. Reproduction 2004, 127 : 239-254.

[24] Braw-Tal R, Tisdall DJ, Hudson NL, Smith P, McNatty KP. Follistatin but not alpha or beta A inhibin subunit mRNA is expressed in ovine fetal ovaries in late gestation. J Mol Endocrinol 1994, 13: 1-9.

[25] El-Fouly MA, Cook B, Nekola M, Nalbandov AV. Role of the ovum in follicular luteinization. Endocrinology 1970, 87: 288-293.

[26] Otsuka F, Yao Z, Lee T, Yamamoto S, Erickson GF, Shimasaki S. Bone morphogenetic protein-15. Identification of target cells and biological functions. J Biol Chem 2000, 275: 39523-39528.

[27] Otsuka F, Moore RK, Shimasaki S. Biological function and cellular mechanism of bone morphogenetic protein- 6 in the ovary. J Biol Chem 2001, 276: 32889-32895.

[28] Vitt UA, Hayashi M, Klein C, Hsueh AJ. Growth differentiation factor-9 stimulates proliferation but suppresses the follicle-stimulating hormone-induced differentiation of cultured granulosa cells from small antral and preovulatory rat follicles. Biol Reprod 2000, 62: $370-377$.
[29] Otsuka F, Moore RK, Iemura S, Ueno N, Shimasaki S. Follistatin inhibits the function of the oocyte-derived factor BMP-15. Biochem Biophys Res Commun 2001, 289: $961-$ 966.

[30] Erickson GF, Shimasaki S. The spatiotemporal expression pattern of the bone morphogenetic protein family in rat ovary cell types during the estrous cycle. Reprod Biol Endocrinol 2003, 1. Available from URL: http://www. RBEj.com/content/1/1/9.

[31] Jaatinen R, Rosen V, Tuuri T, Ritvos O. Identification of ovarian granulosa cells as a novel site of expression for bone morphogenetic protein-3 (BMP-3/osteogenin) and regulation of BMP-3 messenger ribonucleic acids by chorionic gonadotropin in cultured human granulosa-luteal cells. J Clin Endocrinol Metab 1996, 81: 3877-3882.

[32] Shimasaki S, Zachow RJ, Li D, Kim H, Iemura S, Ueno N, Sampath K, Chang RJ, Erickson GF. A functional bone morphogenetic protein system in the ovary. Proc Natl Acad Sci USA 1999, 96: 7282-7287.

[33] Souza CJ, Campbell BK, McNeilly AS, Baird DT. Effect of bone morphogenetic protein 2 (BMP2) on oestradiol and inhibin A production by sheep granulosa cells, and localization of BMP receptors in the ovary by immunohistochemistry. Reproduction 2002, 123: 363 369.

[34] Canalis E, Economides AN, Gazzerro E. Bone morphogenetic proteins, their antagonists, and the skeleton. Endocr Rev 2003, 24: 18-35.

[35] Valenzuela DM, Economides AN, Rojas E, Lamb TM, Nunez L, Jones P, Lp NY, Espinosa R 3rd, Brannan CI, Gilbert DJ et al. Identification of mammalian noggin and its expression in the adult nervous system. J Neurosci 1995, 15: 6077-6084.

[36] Millet C, Lemaire P, Orsetti B, Guglielmi P, Francois V. The human chordin gene encodes several differentially expressed spliced variants with distinct BMP opposing activities. Mech Dev 2001, 106: 85-96. 